\title{
Pain evaluation scales for elderly patients with dementia
}

\author{
Escalas de avaliação da dor em pacientes idosos com demência \\ Andressa Caio Eira da Custódia ${ }^{1}$, Flávia de Oliveira Motta Maiaํ, Rita de Cassia Gengo e Silva ${ }^{1}$
}

DOI 10.5935/1806-0013.20150059

\section{ABSTRACT}

BACKGROUND AND OBJECTIVES: Elderly people with dementia are impaired in the way they interpret and communicate pain, being important the use of specific tools for accurate diagnosis. This study aimed at summarizing literature data on tools for pain evaluation in hospitalized elderly patients with dementia. CONTENTS: This is a literature review of the following databases: LILACS, Pubmed/Medline, CINAHL, SCOPUS, Cochrane, Web of Science and Joanna-Briggs Institute. Eligibility criteria were established for studies selection. A specific tool was used for critical evaluation. From 383 studies found, 4 were included in this review. Studies have evaluated the performance of 8 observational or self-report scales.

CONCLUSION: Our study results suggest that observational and self-report scales may be used to evaluate pain in hospitalized elderly patients with dementia, provided the level of cognitive impairment is observed to select the scale, thus avoiding inadequate evaluations and consequently the undertreatment of pain.

Keywords: Dementia, Aged, Pain evaluation.

\section{RESUMO}

JUSTIFICATIVA E OBJETIVOS: Os idosos com demência apresentam comprometimento que afeta o modo como interpretam e comunicam a dor, sendo importante a utilização de instrumentos específicos para o diagnóstico adequado. $\mathrm{O}$ objetivo deste estudo foi sintetizar os dados da literatura sobre os instrumentos utilizados para avaliação da dor em idosos com demência internados.

CONTEÚDO: Trata-se de revisão da literatura, utilizando as bases de dados: LILACS, Pubmed/Medline, CINAHL, SCOPUS, Cochrane, Web of Science e Joanna Briggs-Institute. Critérios de elegibilidade foram estabelecidos para seleção dos estudos. Utilizou-se instrumento específico para avaliação crítica. Foram

1. Universidade de São Paulo, Hospital de Clínicas, Departamento de Enfermagem, São Paulo, SP, Brasil.

Submitted in May 25, 2015.

Accepted for publication in September 17, 2015.

Conflict of interests: none - Sponsoring sources: none.

Correspondence to:

Andressa Caio Eira da Custódia

Av. Dr. Enéas de Carvalho Aguiar, 419

05403-000 São Paulo, SP, Brasil.

E-mail: andressac9@gmail.com

(C) Sociedade Brasileira para o Estudo da Dor localizados 383 estudos, dos quais 4 foram incluídos nesta revisão. Os estudos avaliaram o desempenho de 8 escalas observacionais ou de autorrelato.

CONCLUSÁO: Os resultados deste estudo sugerem que escalas observacionais e de autorrelato podem ser utilizadas para avaliar a dor em idosos com demência em ambiente hospitalar, desde que seja observado o nível de comprometimento cognitivo para a escolha da escala, evitando-se assimavaliaçóes inadequadas e consequentemente o subtratamento da dor.

Descritores: Avaliação da dor, Demência, Idoso.

\section{INTRODUCTION}

Pain is a sensory and unpleasant experience, resulting from real or potential injury to body tissues ${ }^{1}$. Painful sensation verbalization is the golden standard for its diagnosis ${ }^{2}$ and that is why neurocognitive disorders may be a major challenge for health professionals when diagnosing and handling pain ${ }^{3,4}$.

Cognitive impairment, which is present in elderly people with dementia, may affect different aspects involved in pain manifestation. In other words, identifying pain goes beyond individuals' ability to perceive and interpret the experience (judgment) and to manifest ${ }^{5}$ it verbally or by other means (language $)^{6}$. In addition, behavioral changes in patients with advanced dementia may be interpreted as baseline disease symptoms, instead of manifestation of pain or discomfort.

In this context, it is important to understand specific tools to diagnose pain in this population, especially in the hospital. Having this information may contribute to support diagnostic decisions of health professionals.

This study aimed at summarizing literature data on tools being used to evaluate pain in hospitalized elderly people with dementia.

\section{CONTENTS}

This is a literature review carried out from April to October 2014, in LILACS, Pubmed/Medline, CINAHL, SCOPUS, Cochrane, Web of Science and Joanna Briggs-Institute databases, which intended to answer the following research question: which are the available tools to evaluate pain in hospitalized elderly people with dementia?

Primary studies published in the last 10 years (2005 to 2014) in English, Spanish and Portuguese, aiming at using tools to evaluate pain in hospitalized elderly with dementia were included. Studies not available online in full and those with poor methodological quality were excluded. 
Keywords were: elderly, elderly aged 80 years or above, dementia, pain measurement, pain evaluation tools and their correlates in each database.

For pre-selection, titles and abstracts were initially read. Articles selected for full reading were independently evaluated by three researchers who, by means of consensus, decided for their maintenance or not in the final review sample. Figure 1 shows the flowchart of selection of studies to be part of the sample.

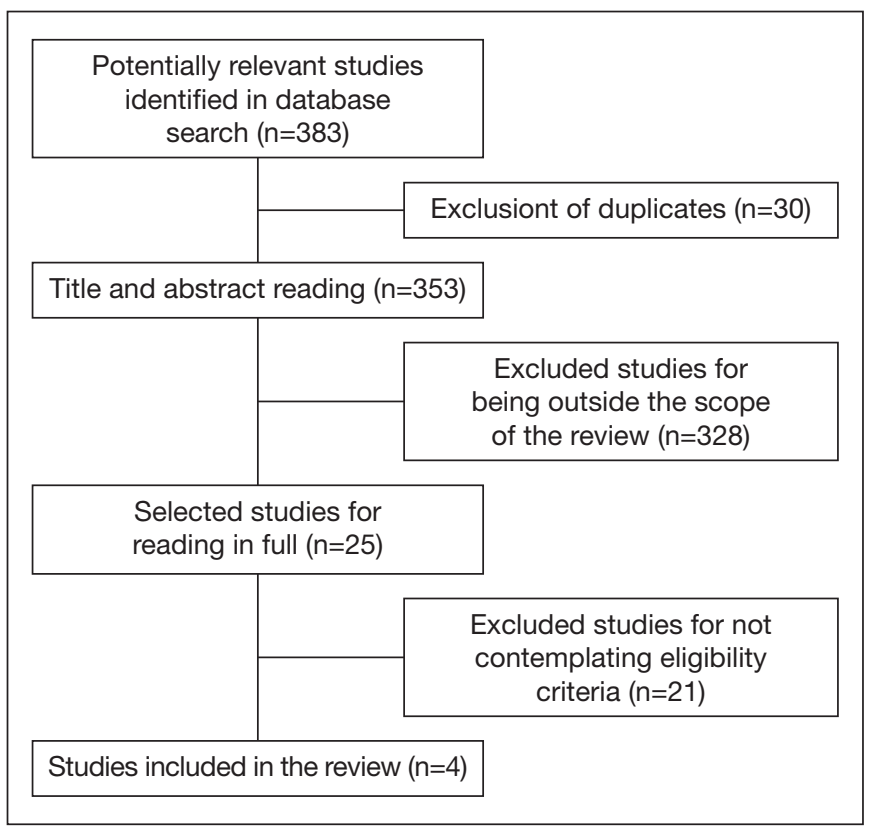

Figure 1. Flowchart of selection stages of studies for systematic review structuring, São Paulo 2015

\section{Data collection and articles review}

Data were collected by means of a structured tool and the methodological quality of included studies was evaluated according to Strengthening the Reporting of Observational Studies in Epidemiology (STROBE) criteria.

One systematic review evaluating pain in patients with dementia was found, however not specifically in a hospital, and so it was discarded from this review.

Due to the heterogeneity of selected studies, results were descriptively evaluated. The summary of articles included in this review is shown in table 1 .

\section{DISCUSSION}

From 383 localized studies, four were included in the review. In all, participants mean age was above 80 years and most were females. The predominance of long-lived elderly in selected studies is compatible with the literature which shows direct relationship of dementia with advanced age ${ }^{7}$.

Pain evaluation scales were observational and self-report scales: Pain Assessment Advanced Dementia Scale (PAINAD), Verbal Rating Scale-5 (VRS5), Verbal Rating Scale-6 (VRS6), visual analog scale (VAS), facial pain scale (FPS), Behavioral Pain Assessment in the Elderly (DOLOPLUS-2), Red Wedge Scale (RWS) and McGill questionnaire.

PAINAD was developed to evaluate pain in individuals with advanced dementia and is made up of five observation items: breathing, negative vocalization, facial expression, body language and consolability ${ }^{7}$. This scale has increased pain detection and the use of analgesics, as compared to numerical scale evaluation ${ }^{7}$.

Table 1. Summary of articles found. São Paulo, 2015

\begin{tabular}{|c|c|c|c|}
\hline Authors & Study objectives & Pain evaluation & Results \\
\hline $\begin{array}{l}\text { Hutchison } \\
\text { et al. } .^{7}\end{array}$ & $\begin{array}{l}\text { Check whether PAINAD improves the } \\
\text { ability to detect pain in patients unable to } \\
\text { report it }\end{array}$ & $\begin{array}{l}\text { PAINAD vs NVS } \\
\text { (0 to 10) }\end{array}$ & $\begin{array}{l}\text { Score of pain intensity unawareness was mower for the PAI- } \\
\text { NAD group. Patients evaluated with PAINAD made more use } \\
\text { of analgesics. }\end{array}$ \\
\hline $\begin{array}{l}\text { Pautex et } \\
\text { al. }{ }^{8}\end{array}$ & $\begin{array}{l}\text { Evaluate whether tools routinely used in } \\
\text { the clinical practice and that do not re- } \\
\text { quire long observation times are reliable } \\
\text { to evaluate pain in patients with different } \\
\text { cognitive impairment levels. }\end{array}$ & $\begin{array}{l}\text { 5-point VRS, VAS, } \\
\text { RWS, FPS \& Mc- } \\
\text { Gill questionnaire }\end{array}$ & $\begin{array}{l}\text { McGill questionnaire was better to evaluate pain intensity as } \\
\text { compared to its quality; it was also better to estimate the affec- } \\
\text { tive component of pain as compared to other scales. Patients } \\
\text { with cognitive impairment had more difficulty to use RWS, VAS } \\
\text { and FPS; patients with moderate to severe cognitive impair- } \\
\text { ment were more skilled in using VRS. }\end{array}$ \\
\hline Herr et al. ${ }^{9}$ & $\begin{array}{l}\text { Evaluate the performance of self-evalu- } \\
\text { ation scales in hospitalized patients with } \\
\text { severe dementia, and compare with ob- } \\
\text { servational data. }\end{array}$ & $\begin{array}{l}\text { 6-point VRS, VAS, } \\
\text { VPS, DOLOP- } \\
\text { LUS-2 }\end{array}$ & $\begin{array}{l}2 / 3 \text { of patients were able to use self-evaluation pain scales. For } \\
\text { patients with good understanding, reliability of self-evaluation } \\
\text { scales was satisfactory. Correlation among self-evaluation } \\
\text { scales has varied from moderate to strong ( } r=0.45 \text { to } 0.94 \text {, } \\
\text { p }<0.001 \text { ), being the strongest correlation between VRS and } \\
\text { FPS; DOLOPLUS- } 2 \text { had moderate correlation with self-evalu- } \\
\text { ation scales. }\end{array}$ \\
\hline Pesonen $^{10}$ & $\begin{array}{l}\text { Report psychometric properties and the } \\
\text { performance of DOLOPLUS-2 observa- } \\
\text { tional scale }\end{array}$ & $\begin{array}{l}\text { DOLOPLUS-2, } \\
\text { VAS }\end{array}$ & $\begin{array}{l}\text { DOLOPLUS- } 2 \text { and VAS scores had moderate correlation; it was } \\
\text { observed that the correlation was stronger in patients without } \\
\text { dementia }(0 . c ̧ 68) \text { as compared to those with dementia }(0.38) \text {. } \\
\text { Internal consistency of DOLOPLUS- } 2 \text { was higher when applied } \\
\text { to patients without dementia as compared to those with de- } \\
\text { mentia (Cronbach alpha }=0.835 \text { and } 0.667 \text {, respectively). }\end{array}$ \\
\hline
\end{tabular}


DOLOPLUS-2 scale ${ }^{8}$ is characterized by the evaluation of verbal complaints, facial expressions, protective body postures, sleep pattern, behavioral problems, functional limitations, changes in communication and social life. Correlation and discriminating ability of DOLOPLUS-2 were lower for dementia patients as compared to VAS self-report scale. Although DOLOPLUS-2 and VAS are different tools in their composition, which could influence correlation analysis, what calls the attention is their poorer performance in patients with dementia as compared to patients without dementia in the study itself ${ }^{8}$.

Self-report scales had different results with regard to variability in identifying pain, considering different levels of patients' cognitive impairment. Scales used had different characteristics for pain self-report: VRS requires patients to describe pain with words, scoring its intensity; VAS may be represented by a $10-\mathrm{cm}$ ruler where each point represents current pain level; RWS is a variation of VAS using a red line to indicate pain intensity; and with FPS patients choose, in a row of six faces, the face that best represents their pain intensity ${ }^{9,10}$.

According to characteristics of each scale, it is observed that at evaluation time patients must have preserved cognition and be able to understand and judge what best expresses their pain. In this sense, study results show that the higher the Mental State Mini Exam (MSME) score ${ }^{11}$, the better the reliability estimates of self-report scales ${ }^{12}$. It should also be stressed that, among evaluated scales, VAS had better pain evaluation results in patients with moderate to severe cognitive impairment ${ }^{11}$.

Other studies substantiate such results, confirming the possibility of pain diagnosis with the use of self-report scales in patients with dementia, as from their ability to interpret and translate into words their pain intensity. On the other hand, the use of facial pain scales may increase the possibility of confusion with feelings and impair the translation of reported pain $^{9,10,13}$.

Limitations of this study were the choice of hospital environment, which has limited the identification of studies on the subject, and the heterogeneity of methodological procedures of selected studies, which has made difficult the analysis of data.

\section{CONCLUSION}

This study has contributed to stress the importance of pain evaluation systematization in hospitalized patients with de- mentia, a difficult and extremely important task for the clinical practice.

Eight scales were identified to be used in this specific population with different cognitive impairment levels. Among observational scales, PAINAD has shown increased pain detection and improved treatment with the use of analgesics.

Self-report scales were better for patients with less severe cognitive impairment and VRS has provided more consistent results for pain evaluation in the elderly with moderate to severe cognitive impairment.

Results of this review suggest that observational and self-report scales may be used to evaluate pain in hospitalized elderly with dementia, provided the level of cognitive impairment is taken into consideration when choosing the scale, thus avoiding inadequate evaluations and consequent undertreatment of pain.

\section{REFERENCES}

1. Merskey H, Bogduk N. International Association for the Study of Pain. Classification of Chronic Pain. $2^{\text {nd }}$ ed. IASP Task Force on Taxonomy. Seattle; 1994 [acesso 2014 Set 13]. Disponível em: http://www.iasp-pain.org/Education/Content.aspx?ItemNumber $=1698 \&$ navitemNumber $=576 \#$ Pain.

2. Ando C, Hishinuma M. Development of the Japonese DOLOPLUS-2: a pain assessment scale for the elderly with Alzheimr's disease. Psychogeriatrics. 2010;10(3):131-7.

3. Lorenzet IC, Santos FC, Souza PM, Gambarro RC, Coelho S, Cendoroglo MS. Avaliaçăo da dor em idosos com demência: traduçăo e adaptaçáo transcultural do instrumento PACSLAC para a língua portuguesa. RBM. 2011;68(4):129-33.

4. Lautenbacher S, Niewelt BG, Kunz M. Decoding pain from the facial display of patients with dementia: a comparison of professional and nonprofessional observers. Pain Med. 2013;14(4):469-77.

5. Scherder E, Oosterman J, Swaab D, Herr K, Ooms M, Ribbe M, et al. Recent developments in pain in dementia. BMJ. 2005;330(7489):461-4

6. Burlá C, Camarano AA, Kanso S, Fernandes D, Nunes R. [A perspective overview of dementia in Brazil: a demographic approach]. Cienc Saude Colet. 2013;18(10):294956. Portuguese.

7. Hutchison RW, Tucker WF Jr, Kim S, Gilder R. Evaluation of a behavioral assessment tool for the individual unable to self-report pain. Am J Hosp Palliat Care. 2006;23(4):328-31.

8. Pautex S, Herrmann FR, Michon A, Giannakopoulos P, Gold G. Psychometrics properties of the Doloplus-2 observational pain assessment scale and comparison to selfassessment in hospitalized elderly. Clin J Pain. 2007;23(9):774-9.

9. Herr K, Bursch H, Ersek M, Miller LL, Swafford K. Use of pain-behavioral assessment tools in the nursing home: expert consensus recommendations for practice. J Gerontol Nurs. 2010;36(3):18-29.

10. Pesonen A. Pain measurement and management in the elderly patients: clinical studies in long term hospital care and after cardiac surgery [dissertaçáo na Internet]. Helsinki, Finland: Department of Anaesthesiology and Intensive Care; 2011 [acesso em $2015 \mathrm{Fev}$ 10]. Disponível em: http://www.jpsmjournal.com/article/S0885-3924(05)00611-1/pdf.

11. Pesonen A, Kauppila T, Tarkkila P, Sutela A, Niinistö L, Hosenberg PH. Evaluation of easily applicable pain measurement tools for the assessment of pain in demented patients. Acta Anaesthesiol Scand. 2009;53(5):657-64.

12. Pautex S, Michon A, Guedira M, Emond H, Le Lous P, Samaras D, et al. Pain in severe dementia: self assessment or observational scales? J Am Geriatr Soc. 2006;54(7):1040-5.

13. Herr K, Bjoro KF, Decker $S$. Tools for assessment of pain in nonverbal older adults with dementia: a state-of-the-science review. J Pain Symptom Manage. 2006;31(2):170-92. 